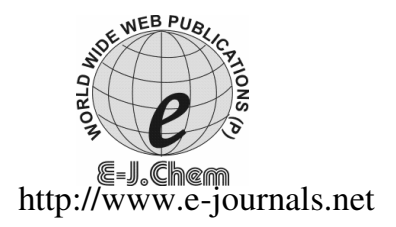

ISSN: 0973-4945; CODEN ECJHAO
E-Journal of Chemistry
$2011, \mathbf{8 ( 4 )}, 1815-1819$

\title{
Development of Validated Spectrophotometric Methods for Estimation of Ethacridine Lactate in Pharmaceutical Formulations
}

\author{
AZIZ UNNISA*, N. MANASA and P. LAKSHMI RAVALI \\ K.V.S.R Siddhartha College of Pharmaceutical Sciences \\ Vijayawada, AP- 520010, India \\ khushiazeez@yahoo.co.in
}

Received 19 December 2010; Accepted 28 February 2011

\begin{abstract}
Ethacridine lactate (EAL) is an antiseptic in solutions of $0.1 \%$. It is also used as an agent for second trimester abortion. Two simple and sensitive spectrophotometric methods (Method A and Method B) were developed for the estimation of EAL in pharmaceutical formulations. Method A is based on the condensation of the primary aromatic amino group of ethacridine lactate with an aromatic aldehyde ( $p$-Dimethylaminocinnamaldehyde) to form a chromophore with absorption maximum of $600 \mathrm{~nm}$. Method B is based on redox reaction followed by complex formation of EAL with $\mathrm{IO}_{3}{ }^{-} /$Metol reagent to form a stable chromogen, which can be estimated at $520 \mathrm{~nm}$. Method A obeys Beer's law in the concentration range of 2 to $12 \mu \mathrm{g} / \mathrm{mL}$ and method $\mathrm{B}$ in the range of 20 to $100 \mu \mathrm{g} / \mathrm{mL}$. Interference studies were conducted to see the influence of excipients with the proposed methods. The common excipients usually present in dosage forms do not interfere in the proposed method A and method B. The optical characteristics, regression analysis data and precision of the methods were also calculated. The methods were validated for use in routine quality control of EAL in pharmaceutical formulations.
\end{abstract}

Keywords: Ethacridine lactate, $p$-Dimethylaminocinnamaldehyde, Metol

\section{Introduction}

Ethacridine lactate ${ }^{1-4}$ is an antiseptic in solutions of $0.1 \%$; it is also used as an agent for second trimester abortion. Up to $150 \mathrm{~mL}$ of $0.1 \%$ solution is instilled extra amniotically using a foley catheter. Ethacredine as an abortificeant is found to be safer and better tolerated then $20 \%$ hypertonic saline. The chemical name of ethacridine lactate is 2-ethoxy-6,9-diamino acridine monolactate monohydrate. For the estimation of ethacridine lactate few HPLC 
Methods ${ }^{5-8}$ were reported. The present investigation is to develop two simple and sensitive spectrophotometric methods for the estimation of EAL in pharmaceutical formulations based on; (a) The condensation of the primary aromatic amino group of EAL with $p$-dimethylaminocinnamaldehyde (PDAC) ${ }^{9}$ and (b) The redox reaction followed by complex formation of EAL with $\mathrm{IO}_{3}{ }^{-} /$metol reagent ${ }^{10-12}$.

\section{Experimental}

A systronics double beam UV- visible spectrophotometer 2201 with $1 \mathrm{~cm}$ matched quartz cells was used for all spectral and absorbance measurements. A systronics digital $\mathrm{pH}$ meter was used for all pH measurements. Electronic dhona balance 200D was used for weighing the samples. Class 'A' volumetric glassware were used.

\section{Reagents preparation}

- PDAC solution (Loba, $0.2 \% \mathrm{w} / \mathrm{v}, 1.14 \times 10^{-2} \mathrm{M}$ ): Prepared by dissolving $200 \mathrm{mg}$ of p-dimethylaminocinnamaldehyde in $100 \mathrm{~mL}$ of methanol.

- Sulfuric acid solution $\left(\mathrm{CDH}, 10 \% \mathrm{v} / \mathrm{v}, 1.0 \times 10^{-2} \mathrm{M}\right): 10 \mathrm{~mL}$ of sulfuric acid was added to about $50 \mathrm{~mL}$ of ice cooled methanol solvent and finally volume was made up to $100 \mathrm{~mL}$ with methanol at room temperature.

- Metol solution (Qualigens, $0.2 \% \mathrm{w} / \mathrm{v}, 5.81 \times 10^{-3} \mathrm{M}$ ): Prepared by dissolving $200 \mathrm{mg}$ of $p$ - $N$-methylaminophenol in $100 \mathrm{~mL}$ of distilled water.

- $\mathrm{KIO}_{3}$ solution (Merck, $0.43 \%, 2.0 \times 10^{-2} \mathrm{M}$ ): Prepared by dissolving $430 \mathrm{mg}$ of potassium iodate in $100 \mathrm{~mL}$ of distilled water.

- $\quad \mathrm{pH} 3.1$ buffer solution: Prepared by diluting a mixture of $50 \mathrm{~mL}$ of $0.2 \mathrm{M}$ potassium hydrogen phthalate and $19 \mathrm{~mL}$ of $0.2 \mathrm{~N} \mathrm{HCl}$ to $200 \mathrm{~mL}$ with water and the $\mathrm{pH}$ was adjusted to 3.1 .

\section{Standard preparation}

The stock solution $(1 \mathrm{mg} / \mathrm{mL})$ of EAL was prepared by dissolving $100 \mathrm{mg}$ of the EAL in $100 \mathrm{~mL}$ of methanol. For Method A, this stock solution was suitably diluted with methanol to get working standard solution having a concentration of $100 \mu \mathrm{g} / \mathrm{mL}$.

\section{Sample preparation}

The content of ten vials was taken and thoroughly mixed. From this an accurately measured portion of the liquid content equivalent to $100 \mathrm{mg}$ of the drug was taken and diluted to $100 \mathrm{~mL}$ with methanol. Later this solution was further diluted to get absorbance values within the calibration curve range.

\section{Procedure for assay}

\section{Method A}

To a series of $10 \mathrm{~mL}$ volumetric flasks, methanolic EAL standard solution $(100 \mu \mathrm{g} / \mathrm{mL})$ ranging from 0.2 to $1.2 \mathrm{~mL}$ was transferred and $1.0 \mathrm{~mL}$ of PDAC followed by $1 \mathrm{~mL}$ of $10 \%$ sulfuric acid. The final volume was adjusted to $10 \mathrm{~mL}$ with methanol. The absorbance was measured at $530 \mathrm{~nm}$ against the reagent blank. The amount of EAL present in the given sample solution was computed from its calibration curve.

\section{Method B}

Into a series of $25 \mathrm{~mL}$ volumetric flasks, $15 \mathrm{~mL}$ of pH 3.1 buffer, $1.0 \mathrm{~mL}$ of $0.02 \mathrm{M} \mathrm{KIO}_{3}$ solution and $2.0 \mathrm{~mL}$ of $0.2 \%$ metol solution were successively placed. To this standard solution $(1000 \mu \mathrm{g} / \mathrm{mL})$ of EAL in the range of $0.5-2.5 \mathrm{~mL}$ were added. The final volume in 
each flask was made up to the mark with distilled water. The absorbance of the solutions was measured at $520 \mathrm{~nm}$ after 20 min against the reagent blank. The amount of EAL in test was computed from the corresponding Beer-Lambert's plot.

\section{Results and Discussion}

\section{Method A}

This method is based on the formation of Schiff's base of EAL with p-dimethylaminocinnamaldehyde as shown in Scheme 1.

\section{Method B}

The color development is due to the formation of a CT complex as represented in Scheme 2. The composition of colored species formed between PMBQMI and EAL can be explained as per the analogy of earlier workers.<smiles>CCOc1ccc2nc3cc(N/C=C\c4ccc(N(C)C)cc4)ccc3c(N/C=C/C=C/c3ccc(N(C)C)cc3)c2c1</smiles><smiles>CNc1ccc(OC)cc1</smiles>

(p-N-methyl benzoquinone monoimine)

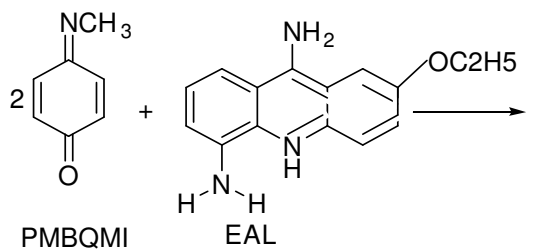

\section{Scheme 2}

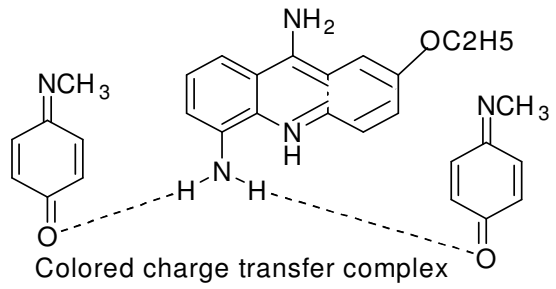

Interference studies were conducted to see the influence of excipients with the proposed methods. The common excipients usually present in dosage forms do not interfere in the proposed method A and method B. The optical characteristics, regression analysis data and precision of the methods are presented in Table 1 . The results of accuracy were given in Table 2. 
Table 1. Optical characteristics and regression analysis parameters

\begin{tabular}{|c|c|c|}
\hline Parameter & Method A & Method B \\
\hline$\lambda_{\max }, \mathrm{nm}$ & 600 & 520 \\
\hline Beer's law limits, $\mu \mathrm{g} \mathrm{mL}{ }^{-1}$ & $2-12$ & $20-100$ \\
\hline Molar absorptivity, $1 \mathrm{~mole}^{-1} \mathrm{~cm}^{-1}$ & $2.39 \times 10^{4}$ & $2.82 \times 10^{3}$ \\
\hline Detection limits, $\mu \mathrm{g} \mathrm{mL}^{-1}$ & 0.857 & 1.683 \\
\hline $\begin{array}{l}\text { Sandell's sensitivity, } \\
\mu \mathrm{g} \mathrm{cm}^{-2} / 0.001 \text { absorbance unit }\end{array}$ & 0.015 & 0.127 \\
\hline Optimum photometric range, $\mu \mathrm{g} \mathrm{mL}^{-1}$ & $4-10$ & $20-80$ \\
\hline Regression equation $(\mathrm{Y}=\mathrm{a}+\mathrm{bc})^{*}$ Slope $(\mathrm{b})$ & 0.066 & 0.008 \\
\hline Standard deviation of slope $\left(S_{b}\right)$ & $1.53 \times 10^{-4}$ & $6.65 \mathrm{E}-05$ \\
\hline Intercept (a) & 0.001 & -0.0018 \\
\hline Standard deviation of intercept $\left(\mathrm{S}_{\mathrm{a}}\right)$ & $1.10 \times 10^{-3}$ & $4.03 \times 10^{-3}$ \\
\hline Standard error of estimation $\left(\mathrm{S}_{\mathrm{e}}\right)$ & $1.62 \times 10^{-3}$ & $5.57 \times 10^{-3}$ \\
\hline Correlation coefficient (r) & 0.9999 & 0.9999 \\
\hline Relative standard deviation, $\%^{*}$ & 0.39 & 0.656 \\
\hline \multicolumn{3}{|l|}{$\%$ Range of error (Confidence limits) ${ }^{* *}$} \\
\hline 0.05 level & 0.0008 & 0.75 \\
\hline 0.01 level & 0.001 & 0.95 \\
\hline$\%$ Error in bulk samples ${ }^{* * *}$ & 0.06 & 0.71 \\
\hline
\end{tabular}

${ }^{*} y=a+b x$, where ' $x$ ' is the concentration of $E A L$ in $\mu g / m L$ and $y$ is the absorbance value. ${ }^{* *}$ Average of six determinations. ${ }^{* * *}$ Average of three determinations

Table 2. Estimation of ethacridine lactate in pharmaceutical formulations

\begin{tabular}{|c|c|c|c|c|c|c|c|}
\hline \multirow{2}{*}{ 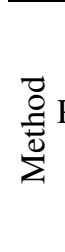 } & \multirow{2}{*}{$\begin{array}{l}\text { Pharmaceutical } \\
\text { Formulation }\end{array}$} & \multirow{2}{*}{$\begin{array}{l}\text { Labelled } \\
\text { Amount, } \\
\text { mg/mL }\end{array}$} & \multicolumn{3}{|c|}{ Proposed method } & \multirow{2}{*}{$\begin{array}{c}\text { Found by } \\
\text { reference } \\
\text { method } \pm \\
\text { S.D }\end{array}$} & \multirow{2}{*}{$\begin{array}{c}\% \\
\text { Recovery } \\
\text { by } \\
\text { proposed } \\
\text { methods } \\
\pm \text { S.D }\end{array}$} \\
\hline & & & $\begin{array}{c}\text { Amount } \\
\text { found*, } \\
\mathrm{mg} \pm \text { S.D }\end{array}$ & $\begin{array}{c}\mathrm{t} \\
\text { (Value) }\end{array}$ & $\begin{array}{c}\text { F } \\
\text { (Value) }\end{array}$ & & \\
\hline $\mathrm{A}$ & Injection & 1 & $0.97 \pm 0.013$ & 0.271 & 1.401 & $1 \pm 0.009$ & $99.88 \pm 0.25$ \\
\hline $\mathrm{B}$ & Injection & 1 & $1.03 \pm 0.011$ & 0.328 & 1.258 & $0.96 \pm 0.012$ & $100.1 \pm 0.81$ \\
\hline
\end{tabular}

\section{Conclusion}

The proposed methods are economic, simple, sensitive, reproducible and accurate and can be used for the routine analysis of EAL in bulk as well as in its pharmaceutical preparations.

\section{Acknowledgment}

The authors are grateful to Siddhartha Academy, Vijayawada, for providing the necessary facilities. 


\section{References}

1. Gupta S, Sachdeva L and Gupta R, Indian J Matern Child Health, 1993, 4, 59-61.

2. Bhathena B K, Sheriar N K, Walvekar V R, et al Br J Obstet Gynaecol.. 1990, 97(11), 1026-1029.

3. Laul R M, Mahale A R and Bhattacharya P R, Asia Oceania J Obstet Gynaecol., 1984, 10(2), 185-189.

4. Shukla S, Sapre S and Olyai P, J Indian Med Assoc., 1984, 82(12), 432-434.

5. Guo Z, Wei D, Gan N, Xie H and Yu X, J Chromatogr Sci., 2007, 45, 325-329.

6. Akada Y, Kawano S and Tanase Y, Yakugaku Zasshi., 1980, 100(7), 766-770.

7. Akada Y, Morishita H and Kono S, Tanase Y, Yakugaku Zassh., 1977, 97(4), 455-458.

8. Zhi-Yong Guo, Dan-Yi Wei, Yuan-Yuan Wang, Biomedical Chromatogr., 2007, 21, 480.

9. Siggia S and Hanna J G, Quantitative Organic Analysis via Functional Groups $4^{\text {th }}$ Edn., Wiley - Interscience, New York, 1979.

10. Siraj P, Ramakrishna R, Murthy S S N. and Sastry C S P, Nat acad Sci lett., 1979, 2(11), 413-415.

11. Ramakrishna R, Siraj P and Sastry C S P, Z Anal Chem., 1980, 303(5), 411.

12. Ramakrishna R, Siraj P and Sastry C S P, Curr Sci., 1979, 48, 815-816. 


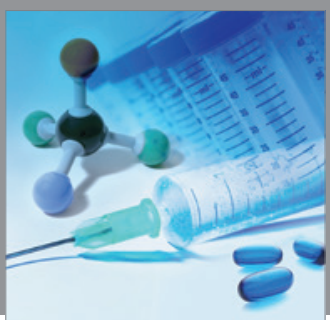

International Journal of

Medicinal Chemistry

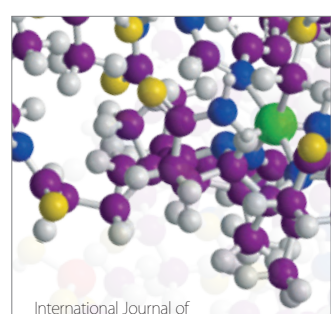

Carbohydrate Chemistry

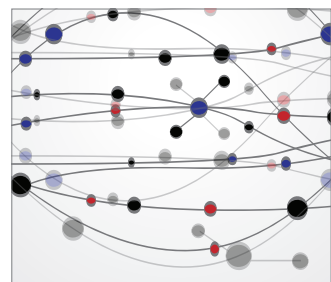

The Scientific World Journal
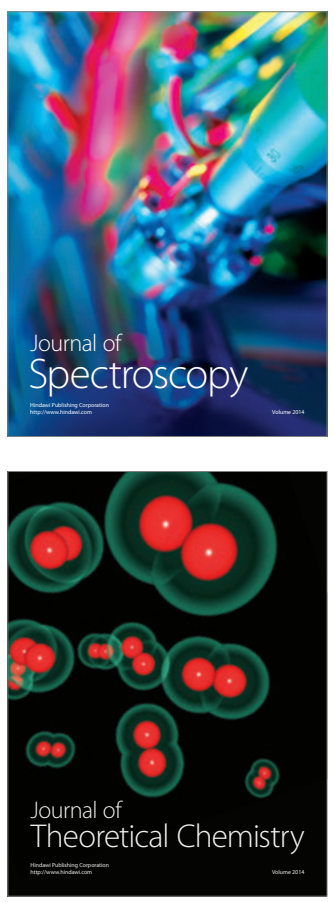
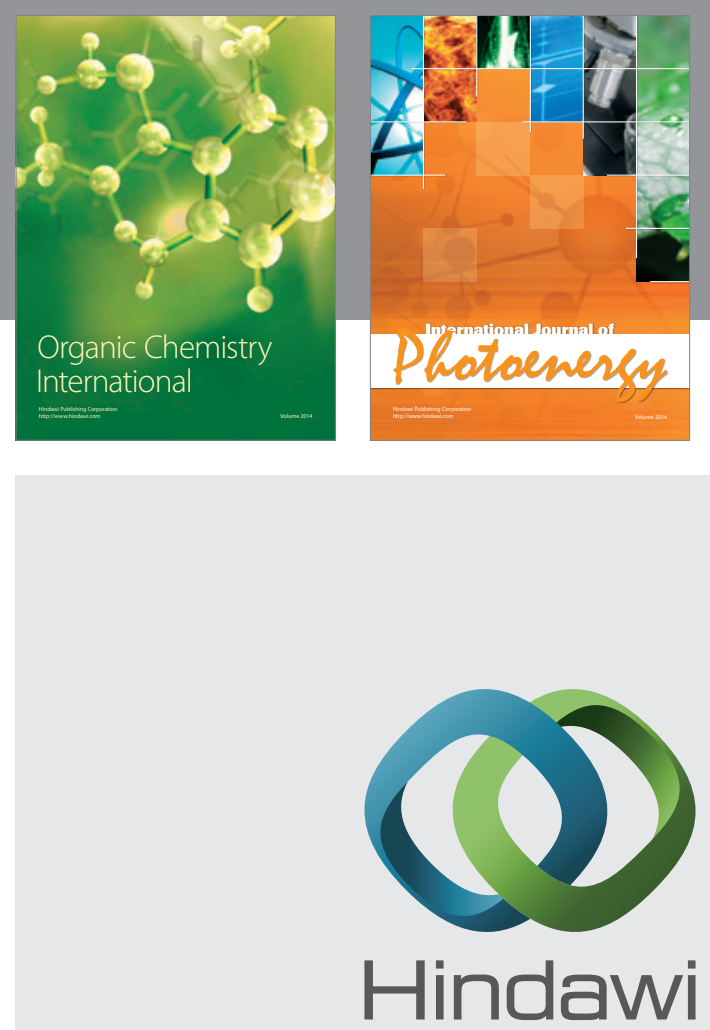

Submit your manuscripts at

http://www.hindawi.com
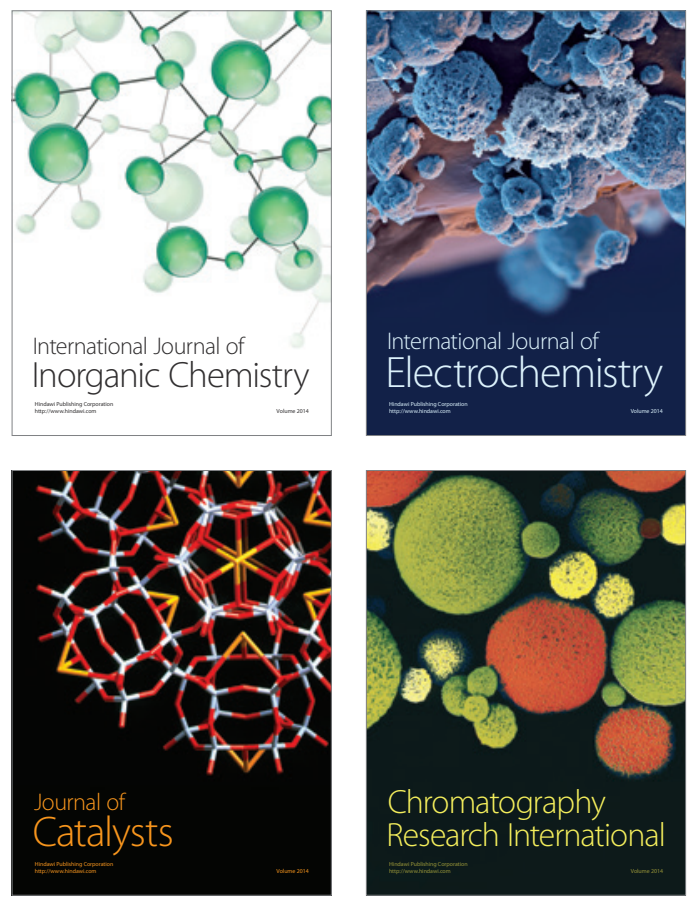
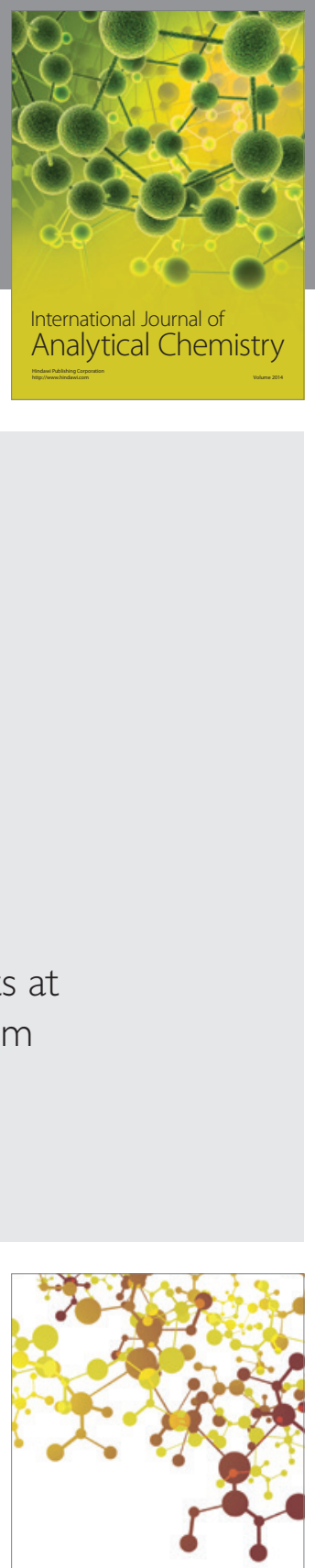

Journal of

Applied Chemistry
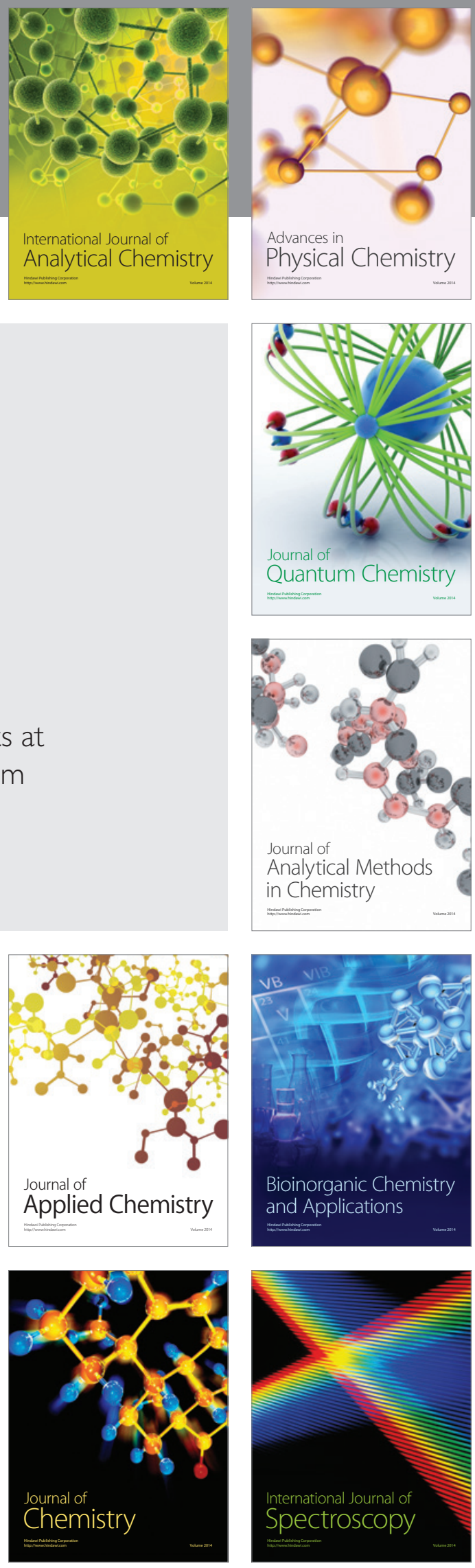